\title{
Universidad Miguel de Cervantes: Productividad Académica a partir de la Inter y Transdisciplinariedad
}

\author{
Abg. Gutenberg Martínez Ocamica \\ Universidad Miguel de Cervantes, UMC \\ gmartinez@umcervantes.cl \\ Talca, Chile \\ https://orcid.org/0000-0003-3759-0457
}

\section{Editorial}

Para la Universidad Miguel de Cervantes (UMC), es un hito muy relevante que la Revista Scientific (e-ISSN: 2542-2987), del Instituto Internacional de Investigación y Desarrollo Tecnológico Educativo (INDTEC), nos haya invitado a participar de su número especial de Educación e Investigación, pues, si bien la presencia de la Universidad en nuestro país en el área de educación es de larga data, lo que ha permitido consolidar una oferta de formación posgradual en el área, el desarrollo de la investigación, por parte de los núcleos de investigadores de los programas, es un elemento que desde esta perspectiva es reciente data.

En ese sentido, cobran mayor importancia las comunidades epistémicas, desempeñando un papel protagónico, a fin de abordar los problemas científicos, tal como lo afirma, Arocena (2003), citado por Bianco y Sutz (2014), al plantear que:

Ensayar alternativas nuevas implica riesgos varios, ante todo el de equivocarse. El carácter muy poco democrático del conocimiento avanzado responde, en proporciones diversas según los casos, a su complejidad intrínseca y a las dinámicas grupales de los especialistas. No prestar debida atención a lo primero lleva fácilmente por el camino de la demagogia; descuidar el peso de lo segundo puede conducir a callejones sin salida (pág. 75).

Por esta razón, es necesario crear las estructuras y espacios de investigación para dar respuesta tanto a dichos problemas planteados desde 
el saber científico, la progresividad de la ciencia y la sociedad, de allí el cambio en las relaciones entre: la ciencia, individuos y espacios de producción científica, abriendo lugar a la colaboración, la gestión del conocimiento inter y transdisciplinario, contribuyendo al desarrollo académico.

Es necesario resaltar que, a nivel universitario, específicamente, en la Universidad Miguel de Cervantes (UMC), se establecen grupos de investigación como espacios epistémicos propicios para la interacción social y educativa, promoviendo la producción tangible desde la academia, lo que prevalece en la universidad, cuyas condiciones, desafíos y cultura organizacional, en distintos contextos latinoamericanos. En definitiva, los grupos de investigación, son una mirada a la definición desde la experiencia, una exploración de los aspectos culturales y sociales que intervienen en la vida académica dentro de la institución donde se desenvuelven los integrantes del grupo reconocido en la Universidad Miguel de Cervantes.

Razón por la cual, autores de la talla de Delgado (2016), consideran:

A pesar del consenso en relación al potencial educativo de la investigación y de ser fundamental en el ámbito universitario, parece faltar una cultura o costumbre (ethos) que la habilite como herramienta de aprendizaje del estudiante e instrumento de trabajo del profesor. Como consecuencia existe una separación entre los saberes de enseñanza y los saberes de investigación (pág. 61).

De esta manera, la investigación en cada uno de estos grupos es relevante, porque estructura y diversifica los procesos de búsqueda del conocimiento dentro y fuera de la institución universitaria, donde el interaccionismo, la acción y reflexión en las diferentes modalidades de los programas educativos presenciales y a distancia tienen una visión holística, materializando las ideas y transformando los paradigmas o formas de ver el mundo en productividad académica, evidenciada en la Universidad Miguel de 
Cervantes, dando respuesta a las demandas sociales, las cuales ofrecen una serie de alternativas de acuerdo al espectro que se plantee.

Por esta razón, los investigadores de la Universidad y, en especial, del núcleo de investigación de los programas de la UMC, han logrado ir posicionándose como un sólido equipo que ha ido avanzando en la reflexión acerca de los diversos aspectos que impactan en el logro de los aprendizajes, pasando desde los condicionantes sociales (segregación y factores exógenos, género), competencias docentes (asertividad, administración) y factores propios (clima, rol docente), hasta el análisis de los impactos de los cambios tecnológicos en el ámbito educacional, que son algunas de las reflexiones que los artículos de este número abordan.

Es de gran importancia para nuestra Universidad, seguir profundizando lazos con instituciones externas en el desarrollo de la investigación que se constituyan en un mejoramiento de la calidad de los sistemas educativos a nivel nacional y latinoamericano, así como a la reflexión acerca de las prácticas que en ellos se desarrollan.

Palabras clave: universidad; productividad; editorial.

Fecha de Recepción: 13-05-2019
Fecha de Aceptación: 19-07-2019
Fecha de Publicación: 05-09-2019 


\section{Universidad Miguel de Cervantes: Academic Productivity from Inter and Transdisciplinarity}

\section{Editorial}

For the Universidad Miguel de Cervantes (UMC), it is a very relevant milestone that the Revista Scientific (e-ISSN: 2542-2987), of the Instituto Internacional de Investigación y Desarrollo Tecnológico Educativo (INDTEC), has invited us to participate in its number Special Education and Research, then, although the presence of the University in our country in the area of education is long-standing, which has allowed us to consolidate an offer of postgraduate training in the area, the development of research, by of the nuclei of researchers of the programs, it is an element that from this perspective is recent data.

In that sense, epistemic communities become more important, playing a leading role, in order to address scientific problems, as stated by Arocena (2003), cited by Bianco and Sutz (2014), by stating that:

Trying new alternatives involves several risks, first of all of being wrong. The very undemocratic nature of advanced knowledge responds, in different proportions depending on the case, to its intrinsic complexity and to the group dynamics of specialists. Not paying due attention to the former easily leads along the path of demagogy; neglecting the weight of the latter can lead to dead ends (p. 75).

For this reason, it is necessary to create the structures and spaces of research to respond both to these problems raised from scientific knowledge, the progressivity of science and society, hence the change in the relationships between: science, individuals and spaces of scientific production, opening space for collaboration, interdisciplinary and interdisciplinary knowledge management, contributing to academic development.

It is necessary to highlight that, at the university level, specifically, at the Universidad Miguel de Cervantes (UMC), research groups are established as 
epistemic spaces conducive to social and educational interaction, promoting tangible production from the academy, which prevails in the University, whose conditions, challenges and organizational culture, in different Latin American contexts. In short, the research groups are a look at the definition from experience, an exploration of the cultural and social aspects that intervene in academic life within the institution where the members of the recognized group at the Miguel de Cervantes University operate.

Reason why, authors of the stature of Delgado (2016), consider: In spite of the consensus regarding the educational potential of research and of being fundamental in the university environment, there seems to be a lack of culture or custom (ethos) that enables it as a student's learning tool and teacher's work instrument. As a result, there is a separation between teaching knowledge and research knowledge (p. 61).

In this way, the research in each of these groups is relevant, because it structures and diversifies the processes of knowledge search inside and outside the university institution, where interactionism, action and reflection in the different modalities of face-to-face educational programs and at a distance they have a holistic vision, materializing ideas and transforming the paradigms or ways of seeing the world in academic productivity, evidenced at the Miguel de Cervantes University, responding to social demands, which offer a series of alternatives according to the spectrum Let it arise.

For this reason, researchers from the University and, especially, from the research nucleus of the UMC programs, have managed to position themselves as a solid team that has been advancing in the reflection on the various aspects that impact on the achievement of learning, from social conditions (segregation and exogenous factors, gender), teaching skills (assertiveness, administration) and own factors (climate, teaching role), to the analysis of the impacts of technological changes in the educational field, which 
are some of the reflections that the articles in this issue address.

It is of great importance for our University, to continue deepening ties with external institutions in the development of research that constitute an improvement in the quality of education systems at the national and Latin American level, as well as reflection on the practices that in They develop.

Keywords: university; productivity; publisher.

Date Received: 13-05-2019
Date Acceptance:

19-07-2019
Date Publication: 05-09-2019 


\section{Referencias}

Arocena, R. (2003). Sobre la democratización del conocimiento y ciertos problemas de la política. En López Cerezo, J. A. La democratización de la ciencia y la tecnología. San Sebastián, España: Editorial Erein, págs. 25-49.

Bianco, M., \& Sutz, J. (2014). Veinte años de políticas de investigación en la Universidad de la República: Aciertos, Dudas y Aprendizajes. Primera edición, ISBN: 978-9974-32-633-0. Montevideo, Uruguay: Ediciones Trilce. Recuperado de: http://www.csic.edu.uy/renderResource/index/resourceld/33750/siteld/ $\underline{3}$

Delgado, L. (2016). Universidad e Investigación. Revista Estomatológica Herediana, 26(2), 61-62, e-ISSN: 2225-7616. Recuperado de: https://doi.org/10.20453/reh.v26i2.2866 


\section{Gutenberg Martínez Ocamica}

e-mail: gmartinez@umcervantes.cl

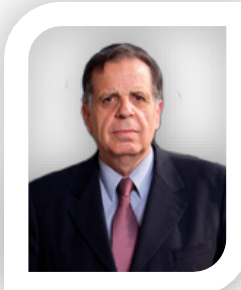

Nació en Santiago, Chile, el 29 de agosto del año 1950. Hijo de Gutenberg Martínez Klein y Victoria Ocamica Jara, nieto de Carlos Alberto Martínez Martínez, casado con María Soledad Alvear, con quien es padre de tres hijos. Realizó sus estudios primarios en el Colegio San Lázaro y en el Liceo de Aplicación; estudió Derecho en la Universidad de Chile, titulándose de Abogado; Presidente de la Universidad Miguel de Cervantes (2002-2009); Presidente Organización Demócrata Cristiana de América, en tres periodos (1998-2006); Presidente de la Cámara de Diputados, en dos periodos (1996-1998); Presidente del Partido Demócrata Cristiano (PDC), en dos periodos (1993-1995) y (1999-2000); Diputado de la República de Chile, en tres periodos consecutivos (1990-2002); ha escrito diversos libros y realizado trabajos y exposiciones sobre temas relacionados con los desafíos de la política, el humanismo cristiano, crecimiento con equidad, el parlamento, desarrollo sustentable, medio ambiente, ciencia y tecnología, Universidad, etc. Entre sus obras se destacan: "Contaminación en Santiago", "Fiscalización Parlamentaria y Comisiones Investigadoras" (1998), de la Editorial Jurídica Andrés Bello; "Un plan de Equidad", editado por ICHEH; "Ponencias 1996-1999", editado por la Cámara de Diputados; "Democracia Cristiana: Cambio y Reforma" (2000), de la Editorial Andante y "Acusaciones Constitucionales" (2004), Editorial Jurídica Andrés Bello, "La palabra y los Pensamientos" (2005), de la Editorial Encrucijada y "Fuentes Doctrinales de la Democracia Cristiana" (2006), por Ediciones ODCA. Actualmente, es Rector de la Universidad Miguel de Cervantes (a partir del año 2010).

El contenido de este manuscrito se difunde bajo una Licencia de Creative Commons ReconocimientoNoComercial-CompartirIgual 4.0 Internacional 